\title{
Environmental pollution and remediation: challenges and management of oil Spillage in the Nigerian coastal areas Adelana S.O ${ }^{1}$, Adeosun.T. ${ }^{2}$, Adesina A. $\mathrm{O}^{1}$ and Ojuroye M.O $\mathrm{O}^{3}$ \\ ${ }^{1}$ Department of Mechanical Engineering,Yaba College of Technology,Lagos,Nigeria \\ ${ }^{2}$ Department of Mathematics, Yaba College of Technology,Lagos,Nigeria \\ ${ }^{3}$ Lano Mechano \&Associates, IKT.,Lagos,Nigeria
}

\begin{abstract}
This paper examines the environmental pollution and remediation of oil spillage in the Nigerian Coastal areas. Oil spillage is one of the greatest environmental problem Nigeria is currently battling with especially in the Niger Delta zone. Oil communities have been at the receiving end of this environmental problem. The problems has generated a lot of concern within of the three tiers of government especially in oil producing states. The coastal area of the Niger Delta is the home to oil explorations and exploitations in Nigeria. Oil spill incidents are common along the Nigeria. The main sources of oil spill on the Niger Delta are: vandalisation of the oil pipelines by the local inhabitants; ageing of the pipelines; oil blow outs from the flow stations; cleaning of oil tankers on the high sea and disposal of used oil into the drains by the road side mechanics. By far the most serious source of oil spill is through the vandalisation of pipelines either as a result of civil disaffection with the political process or as a criminal activity. The paper also delves into the evil of oil spillage facing the Nigeria environment. The Causes, Consequences, Geographic Information System for Managing Oil Spill Incidents and Control Mechanisms were articulated to ameliorate this problem and assist oil communities.
\end{abstract}

Keywords:Environment,spillage,remediation,exploration, pollution,exploitation,pipelines, advection, simulation, anticlinal,bioremediation, phytoremediation, biosurfactants.

\section{INTRODUCTION}

Oil spillage is a release of a liquid petroleum hydrocarbon into the environment due to human activity, and is a form of pollution. The term often refers to marine oil spills, where oil is released into the ocean or coastal waters. Oil spills include releases of crude oil from tankers, offshore platforms, drilling rigs and wells, as well as spills of refined petroleum products (such as gasoline, diesel) and their by-products, and heavier fuels used by large ships such as bunker fuel, or the spill of any oily white substance refuse or waste oil. Spills may take months or even years to clean up. Oil also enters the marine environment from natural oil seeps. Public attention and regulation has tended to focus most sharply on seagoing oil tankers.

Oil spillage is one of the greatest environmental problem Nigeria is currently battling with especially in the Niger Delta zone. Oil communities have been at the receiving end of this environmental problem. The problems has generated a lot of concerns within of the three tiers of government especially in oil producing states.

\section{SOURCES OF OIL SPILLS}

Oil spills may occur for numerous reasons such as equipment failure, disasters, deliberate acts, or human error (Anderson and LaBelle, 2000). Figure 1 shows the percentage each subcategory has contributed to the total number of oil spills in Nigeria in the past five years (Shekwolo,2005). Crude oils are exclusively natural products, most of which are produced from artificial wells. Natural seepage of crude oils occurs in various parts of the world, not only on land, but also on the seabed. Seeps emerge through fractures in the crests of folds in rock formations beneath the sea floor that contain oil and gas deposits.Oil and gas tend to rise and become trapped in anticlinal folds in sub sea rock strata. Seepage occurs through fracture zones where the folds are truncated at the sea floor. Seeps may emanate from a single point or as many as $3 \times 104$ individual seepage signals may be merged onto a high resolution profile record (Clark et al., 2000). 
Am. J. Sci. Ind. Res., 2011, 2(6): 834-845

Table1:Potential sources of Oil Spills

\begin{tabular}{|l|r|}
\hline \multicolumn{2}{|c|}{ POTENTIAL SOURCES OF OIL SPILLS } \\
\hline Sabotage/Bunkering & $36 \%$ \\
\hline Engineering & $0.50 \%$ \\
\hline Human Error & $2 \%$ \\
\hline Corrosion & $36 \%$ \\
\hline Equipment Failure & $6 \%$ \\
\hline Others & $2.50 \%$ \\
\hline
\end{tabular}

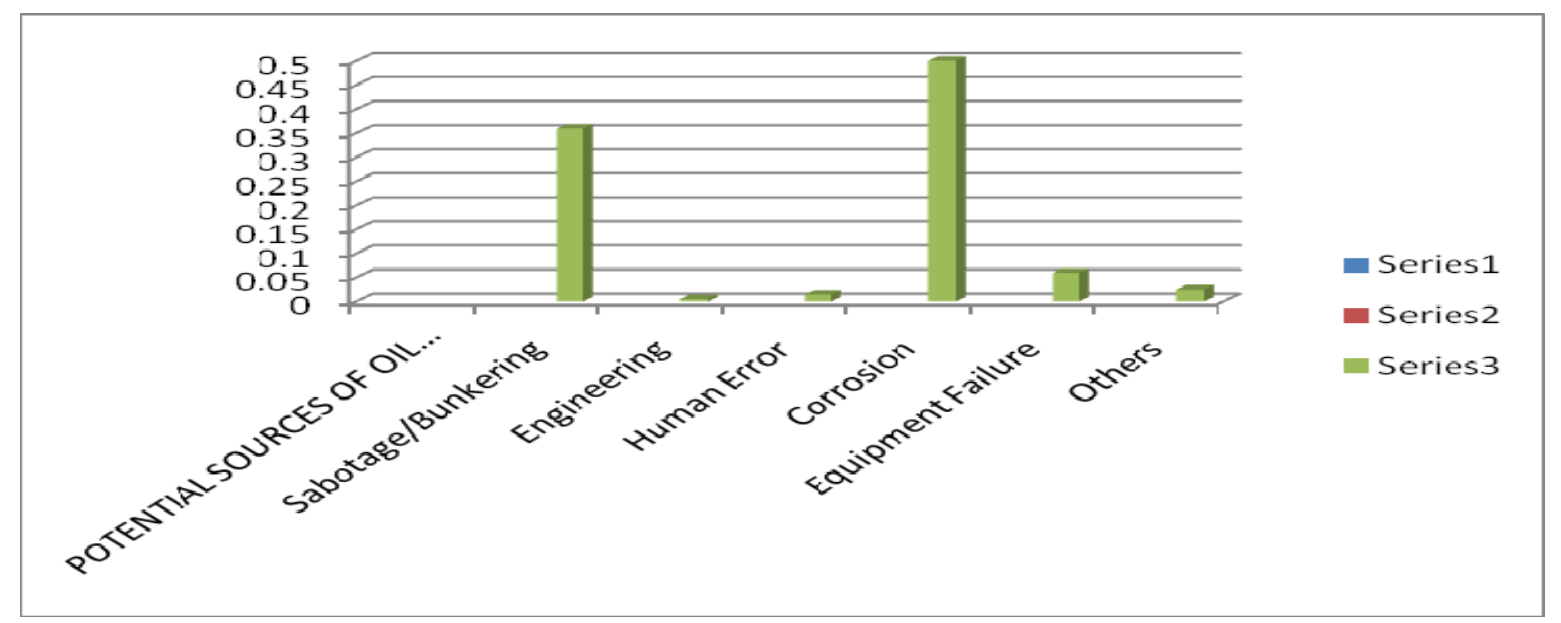

Table 2:Graphical representation of :Potential sources of Oil Spills

Extent of the problem: The Department of Petroleum Resources estimated 1.89 million barrels of petroleum were spilled into the Niger Delta between 1976 and 1996 out of a total of 2.4 million barrels-spilled in 4,835 incidents.(approximately 220 thousand cubic metres).

The Nigerian National Petroleum Corporation places the quantity of petroleum jettisoned into the environment yearly at 2,300 cubic metres with an average of 300 individual spills annually. However, because this amount does not take into account "minor" spills, the World Bank argues that the true quantity of petroleum spilled into the environment could be as much as ten times the officially claimed amount. The largest individual spills include the blowout of a Texaco offshore station which in 1980 dumped an estimated 400,000 barrels $\left(64,000 \mathrm{~m}^{3}\right)$ of crude oil into the Gulf of Guinea and Royal Dutch Shell's Forcados Terminal tank failure which produced a spillage estimated at 580,000 barrels $\left(92,000 \mathrm{~m}^{3}\right)$. In 2010 Baird reported that between 9 million and 13 million barrels have been spilled in the Niger Delta since 1958. One source even calculates that the total amount of petroleum in barrels spilled between 1960 and 1997 is upwards of 100 million barrels $\left(16,000,000 \mathrm{~m}^{3}\right)$.

Causes of oil spillage in Nigeria: Oil spills are a common event in Nigeria and occur due to a number of causes, including: corrosion of pipelines and tankers (accounting for $50 \%$ of all spills), sabotage $(36 \%)$, and oil production operations $(6.5 \%)$, with $1 \%$ of the spills being accounted for by inadequate or non-functional production equipment. The largest contributor to the oil spill total, corrosion of pipes and tanks, is the rupturing or leaking of production infrastructures that are described as, "very old and lack regular inspection and maintenance". A reason that corrosion accounts for such a high percentage of all spills is that as a result of the small size of the oilfields in the Niger Delta, there is an extensive network of pipelines between the fields, as well as numerous small networks of flowlines-the narrow 
diameter pipes that carry oil from wellheads to flowstations-allowing many opportunities for leaks. In onshore areas most pipelines and flowlines are laid above ground. Pipelines, which have an estimate life span of about fifteen years, are old and susceptible to corrosion. Many of the pipelines are as old as twenty to twenty-five years. Even Shell admits that "most of the facilities were constructed between the 1960s and early 1980s to the then prevailing standards. SPDC [Shell Petroleum and Development Company] would not build them that way today." Sabotage is performed primarily through what is known as "bunkering", whereby the saboteur attempts to tap the pipeline. In the process of extraction sometimes the pipeline is damaged or destroyed. Oil extracted in this manner can often be sold.

Sabotage and theft through oil siphoning has become a major issue in the Niger River Delta states as well, contributing to further environmental degradation. Damaged lines may go unnoticed for days, and repair of the damaged pipes takes even longer. Oil siphoning has become a big business, with the stolen oil quickly making its way onto the black market.

While the popularity of selling stolen oil increases, the number of deaths are increasing. In late December 2006 more than 200 people were killed in the Lagos region of Nigeria in an oil line explosion. Nigerian regulations of the oil industry are weak and rarely enforced allowing, in essence, the industry to selfregulate.

Consequences of oil spillage in Nigeria: Oil spillage has a major impact on the ecosystem into which it is released. Immense tracts of the mangrove forests, which are especially susceptible to oil (mainly because it is stored in the soil and re-released annually during inundations), have been destroyed. An estimated 5 to $10 \%$ of Nigerian mangrove ecosystems have been wiped out either by settlement or oil. The rainforest which previously occupied some $7,400 \mathrm{~km}^{2}$ of land has disappeared as well.

Spills in populated areas often spread out over a wide area, destroying crops and aquacultures through contamination of the groundwater and soils. The consumption of dissolved oxygen by bacteria feeding on the spilled hydrocarbons also contributes to the death of fish. In agricultural communities, often a year's supply of food can be destroyed instantaneously. Because of the careless nature of oil operations in the Delta, the environment is growing increasingly uninhabitable.

People in the affected areas complain about health issues including breathing problems and skin lesions; many have lost basic human rights such as health, access to food, clean water, and an ability to work.

Loss of mangrove forests: Vegetation in the Niger River Delta consists of extensive mangrove forests, brackish swamp forests, and rainforests. The large expanses of mangrove forests are estimated to cover approximately 5,000 to $8,580 \mathrm{~km}^{2}$ of land. Mangroves remain very important to the indigenous people of Nigeria as well as to the various organisms that inhabit these ecosystems.

Human impact from poor land management upstream coupled with the constant pollution of petroleum has caused five to ten percent of these mangrove forests to disappear. The volatile, quickly penetrating, and viscous properties of petroleum have wiped out large areas of vegetation. When spills occur close to and within the drainage basin, the hydrologic force of both the river and tides force spilled petroleum to move up into areas of vegetation.

Mangrove forests are included in a highly complex trophic system. If oil directly affects any organism within an ecosystem, it can indirectly affect a host of other organisms. These floral communities rely on nutrient cycling, clean water, sunlight, and proper substrates. With ideal conditions they offer habitat structure, and input of energy via photosynthesis to the organisms they interact with. The effects of petroleum spills on mangroves are known to acidify the soils, halt cellular respiration, and starve roots of vital oxygen.

An area of mangroves that has been destroyed by petroleum may be susceptible to other problems. These areas may not be suitable for any native plant growth until bacteria and microorganisms can remediate the conditions. A particular species of mangrove, Rhizophora racemosa lives higher in the delta system. As the soils supporting $R$. racemosa become too toxic, a non-native invasive species of palm, Nypa fruticans, quickly colonizes the area. This invasive species has a shallower root system that destabilizes the banks along the waterways, further impacting sediment distribution lower in the delta system. $N$. fruticans also impedes navigation and decreases overall biodiversity. In places where $N$. fruticans has invaded, communities are investigating how the palm can be used by local people. 
The loss of mangrove forests is not only degrading life for plants and animals, but for humans as well. These systems are highly valued by the indigenous people living in the affected areas. Mangrove forests have been a major source of wood for local people. They also are important to a variety of species vital to subsistence practices for local indigenous groups, who unfortunately see little to none of the economic benefits of petroleum. Mangroves also provide essential habitat for rare and endangered species like the manatee and pygmy hippopotamus. Poor policy decisions regarding the allocation of petroleum revenue has caused political unrest in Nigeria. This clash among governing bodies, oil corporations, and the people of Nigeria has resulted in sabotage to petroleum pipelines, further exacerbating the threat to mangrove forests.

The future for mangrove forests and other floral communities is not all negative. Local and outside groups have provided funds and labor to remediate and restore the destroyed mangrove swamps. The federal government of Nigeria established the Niger Delta Development Commission (NDDC) in 2000 which aims to suppress the environmental and ecological impacts petroleum has had in the region. Governmental and nongovernmental organizations have also utilized technology to identify the source and movement of petroleum spill.

Depletion of fish populations: The fishing industry is an essential part of Nigeria's sustainability because it provides much needed protein and nutrients for people, but with the higher demand on fishing, fish populations are declining as they are being depleted faster than they are able to restore their number. Fishing needs to be limited along the Niger River and aquacultures should be created to provide for the growing demand on the fishing industry. Aquaculture allows for fish to be farmed for production and provide more jobs for the local people of Nigeria.

Overfishing is not the only impact on marine communities. Climate change, habitat loss, and pollution are all added pressures to these important ecosystems. The banks of the Niger River are desirable and ideal locations for people to settle. The river provides water for drinking, bathing, cleaning, and fishing for both the dinner table and trading to make a profit. As the people have settled along the shores of the rivers and coasts, marine and terrestrial habitats are being lost and ecosystems are being drastically changed. The shoreline along the Niger River is important in maintaining the temperature of the water because the slightest change in water temperature can be fatal to certain marine species. Trees and shrubs provide shade and habitat for marine species, while reducing fluctuation in water temperature.

The Niger River is an important ecosystem that needs to be protected, for it is home to 36 families and nearly 250 species of fish, of which 20 are endemic, meaning they are found nowhere else on Earth. With the loss of habitat and the climate getting warmer, every prevention of temperature increase is necessary to maintain some of the marine environments. Other than restoring habitat, pollution can also be reduced. Problems such as pesticides from agricultural fields could be reduced if a natural pesticide was used, or the fields were moved farther away from the local waterways. Oil pollution can be lowered as well; if spills were reduced then habitat and environmental impacts could be minimized. By limiting the devastation caused by disturbances to the marine environment, such as pollution, overfishing, and habitat loss, the productivity and biodiversity of the marine ecosystems would increase.

\section{Control and management of oil spillage}

Oil Spillage Disaster Management: The Federal Government, oil companies and non-governmental agencies have made severalefforts to manage oil spill disaster along our coastline. These efforts are discussed in the following sections

Nigerian Government Action: To reduce the rate of oil incidents along the Nigerian Coast particularly as a result of vandalisation, the Federal Government through an act of the National Assembly created the

Niger Delta Development Commission (NDDC). Part of the responsibilities of the Commission is to develop a master plan for the development of the Niger Delta, provide infrastructure and create an enabling environment for industrialisation and employment. There are also several other laws dealing with issues related to oil pollution in the environment. Furthermore, standards for the development of the environmental sensitivity index maps for the coast of Nigeria have been developed by the Environmental Systems Research Institute (ESRI). These standards are to be used by all the oil companies to prepare ESI maps for their areas of operations in Nigeria.

A number of Federal and state agencies deal with the problems of oil spill in Nigeria. The agencies include: the Department of Petroleum Resources (DPR), the 
Federal Ministry of Environment, the State Ministries of Environment and the National Maritime Authority.

A National Oil Spill Detection and Response Agency (NOSDRA) has been formed and approved by the Federal Executive Council of Nigeria. The Ministry of environment, which initiated the Agency, has also forwarded to the federal executive council for approval, the reviewed draft National Oil Spill Contingency Plan (NOSCP) which the Agency would manage (Alexandra Gas and Oil Connections, 2006).

The establishment of the contingency plan and the agency was in compliance with the International Convention on Oil Pollution Preparedness, Response and Cooperation (OPRC90) to which Nigeria is a signatory. According to the ministry's sources, the draft bill on the NOSDRA was being put together and would be forwarded to the National Assembly to be enacted into law (Alexandra Gas and Oil Connections, 2006).Apart from intensifying efforts towards compliance monitoring and enforcement of oil and gas regulations and standards, the ministry is also mounting pressure on the oil and gas operators for a gas flare-out. Effort is also being made, according to the sources, to ensure the use of environmental-friendly drilling fluid and mud systems (Alexandra Gas and Oil Connections, 2006)

There is a need to create serious awareness among the populace on the implications of oil spill incidents on the environment. Governments must assist the rural communities in claiming their rights on oil spills and ensure that digital ESI maps are readily available for managing oil spill maps. Government should have strict rules for local oil tankers that would ply our coastal and inland waters as a result of the new cabotage law that is just being passed into law in the country (Nwilo \& Badejo, 2005).

Efforts of the Oil Companies and Non Governmental Agencies: Due to increasing awareness in preventing and controlling spills in Nigeria, the Clean Nigeria Associates (C.N.A.) was formed in November 1981. The C.N.A. is a consortium of eleven oil companies operating in Nigeria, including N.N.P.C. The primary purpose of establishing the C.N.A is to maintain a capability to combat spills of liquid hydrocarbons or pollutants in general (Nwilo \& Badejo, 2005).

Oil spillage can also be treated or removed by natural means, mechanical systems, absorbents, burning, gelling, sinking and dispersion. Oil spillage can be removed by natural means through the process of evaporation, photochemical oxidation and dispersions (Wardley-Smith, 1977). Bioremediation can also be used for managing oil spill problems (Hoff, 1993; Prince, 1993; Atlas, 1995). In addition, apart from the mechanical and chemical oil spill cleaning methods that have been used in managing oil spill problems, oil spill models have on several occasions being used to manage oil spills on the Nigerian Coast (Nwilo \& Badejo, 2005).

Nigerian Sat 1: The Nigerian Sat 1 Satellite has joined the Disaster Monitoring Constellation, an international early-warning satellite network transmitting real-time information about droughts, earthquakes, deforestation and man-made disasters observable from space. The Nigeria Sat-1, an Orbit Satellite for geographical mapping, would also help to check the perennial problem of oil pipeline vandalisation, and assist in combating and managing oil spill incidents. The Nigeria Sat-1, would help in monitoring oil spill by providing the spill position which would serve as input data into the oil spill model. It would also give the extent of coastal water andcoastal areas polluted. These information are vital for quick clean up of oil impacted areas.

International Co-operation: Cracking down on smugglers has proved difficult. To shore up the fight against oil smugglers in Nigeria, the US has donated three 56 metre (180ft) refitted World War two-era patrol oats to the navy. United Nations has also said that United States would donate additional four vessels. The Pentagon is funding each boat's refurbishment to the tune of $\$ 3.5 \mathrm{~m}$. The efforts of the Federal Government with the assistance of the US are already yielding fruits. The Nigerian Navy has intercepted several tankers.

Geographic Information System for Managing Oil Spill Incidents: A successful combating operation to a marine oil spill is dependent on a rapid response from the time the oil spill is reported until it has been fully combated. In order to reduce the response time and qualify the decision-making process, application of Geographic Information Systems (GIS) as an operational tool has been suggested. Information on the exact position and size of the oil spill can be plotted on maps in GIS and a priority of the combat efforts and means according to the identified coastal sensitive areas can be carried out.

GIS offers opportunities for integration of oil drift forecast models (prediction of wind and current influence on the oil spill) in the computer program 
framework (Milaka,1995). Required information for oil spill sensitivity mapping can be depicted on a set of thematic maps using GIS even though they can in theory be depicted onto a single sheet. With the use

of a GIS, however, all the relevant information or themes can be stored in the system and produced onto maps in a format that befits the needs of the day. Alternatively, modeling exercises using the GIS can be conducted to assess the adequacy of any given oil spill contingency plan (Parthiphan, 1994).

The creation of regional spill response centres along coastlines will help in managing oil spill problems (Smith and Loza, 1994). The centres will use oil spill models for combating oil spill problems. Using data collected with an airborne system to input one or several new starting point(s) into the model, will improve the accuracy of the further predictions (Sandberg, 1996).

New oil spill model (NOSM): NOSM simulates the shoreline deposition through an exponential decay function. The movement of oil slick in the model actually represents the movement of the centroid of the slick.

The new oil spill trajectory mathematical model capable of simulating oil transport along our coastal waters came to limelight.. In developing this new mathematical model, the major factors responsible for transporting and advecting oil on water was considered. The assumption made in the work was that oil will not mix with water, and that the density of oil spill is less than that of water, thus the oil spill will move on water and not sink. The work is also limited to oil spill on open coastal water or deep sea. No attempt to model the movement of oil spill on land or on swamps.

Advection is the main mechanism that governs the transportation of suspended and surface oil slick. The combined effects of the following factors advect oil on water:

1. Wind drift current

2. Waves

3. Tides

4. Ocean Current

5. Longshore Current

The advection factors used in the model are described in the following subsections.

Wind Drift Current: The equation for the wind drift current is based on hyberbolic equations given by Officer (1976). The direction of the wind drift current is the sum of the wind direction and a deflection angle. The deflection angle of the wind drift current depends on latitude (Buranapratheprat andTanjaaitrong, 2000).

Eulerian Surface Waves Drift: Sobey and Barker (1996) gave reliable estimates of surface kinematics. Higher order theory for stokes waves predicts that the water particle subject to uniform periodic waves will be transported in the direction of the wave advance. Since the water particle speed $(u)$ given by stokes is the same as the horizontal water particle speed (u), stokes water particle speed was integrated into the Eulerian surface wave drift velocity equation given by Sobey and Barker (1996) to get the speed of the Eulerian surface wave.

Tides: The tidal amplitude and phase for this work is based on the results of Schwiderski's global ocean tidal model and contained in Splaudling et al (1987). The tidal amplitudes and tides were input data into the equations for the speed of tide given by Nelkon and Parker (1982). In a tide wave the horizontal motion, i.e. the particle velocity, is called the tidal stream. The vertical tide is said to rise and fall, and the tidal stream is said to flood and ebb. If the tide is

progressive, the flood direction is that of the wave propagation. If the tide is a standing wave, the flood direction is inland or toward the coast (Canadian Hydrographic Service, 2005).

Ocean Currents: The ocean currents affecting the Nigerian coastal area include the following:

(a.) Surface eastward flowing Guinea Current.

(b.) Subsurface westward and northward flowing Benguela Current.

(c.) Easterly flowing surface North Equatorial Counter Current.

Reddy and Brunnet (1997) gave the ocean current responsible for moving oil as 100 percent of the speed of the ocean current. During the wet season, the Guinea Current and the Easterly Flowing North Equatorial Counter Current are responsible for moving oil spill. The Guinea Current has speeds of $30 \mathrm{cms}-1$ and touches the sea bed at depths shallower than $50 \mathrm{~m}$. From time to time, the Guinea Current reverses it's easternly flow. The reversal is believed to be due to effects of the Benguela Current. The mean eastward velocity for the NECC is $15 \mathrm{~cm}$ $\mathrm{s}-1$. This increases to speeds of more than $30 \mathrm{~cm} \mathrm{~s}-1$ in the Guinea Current (Arnault, 1987). The greatest flow for the NECC occurs in the boreal summer with eastward speeds of up to $29 \mathrm{cms}-1$, which are reduced during the spring. There is a reversal of a majority of the current's flowin the western part of the 
basin during the early months of the year (Arnault, 1987).

During the Dry season, the Benguela current moves the oil spill. Shannon (1985) gathered all available information about surface speed from previous studies and calculated the mean speed of the Benguela Current to be $17 \mathrm{~cm} \mathrm{~s}-1$. (Wedepohl et al. 2000) found that the mean speeds of the current vary from $<11 \mathrm{~cm} \mathrm{~s}-1$ to a maximum of $23 \mathrm{~cm} \mathrm{~s}-1$.

Longshore Currents: The longshore current speed for the work is based on Ibe and Antia, (1983). The longshore current direction for the model is based on Dublin Green et al (1997). Three main longshore drift directions along the Nigerian Coastline were specified by Dublin Green et al (1997).

These directions are:

i. The west-east littoral drift along the western coastline.

ii. The littoral drift off the north western flank of the Niger Delta.

iii. The west-east littoral drift between Akasa point and the Calabar estuary.

The Longshore current directions are given in Figure 1.0 below.

The Longshore current directions are given in Figure 1.0 below.

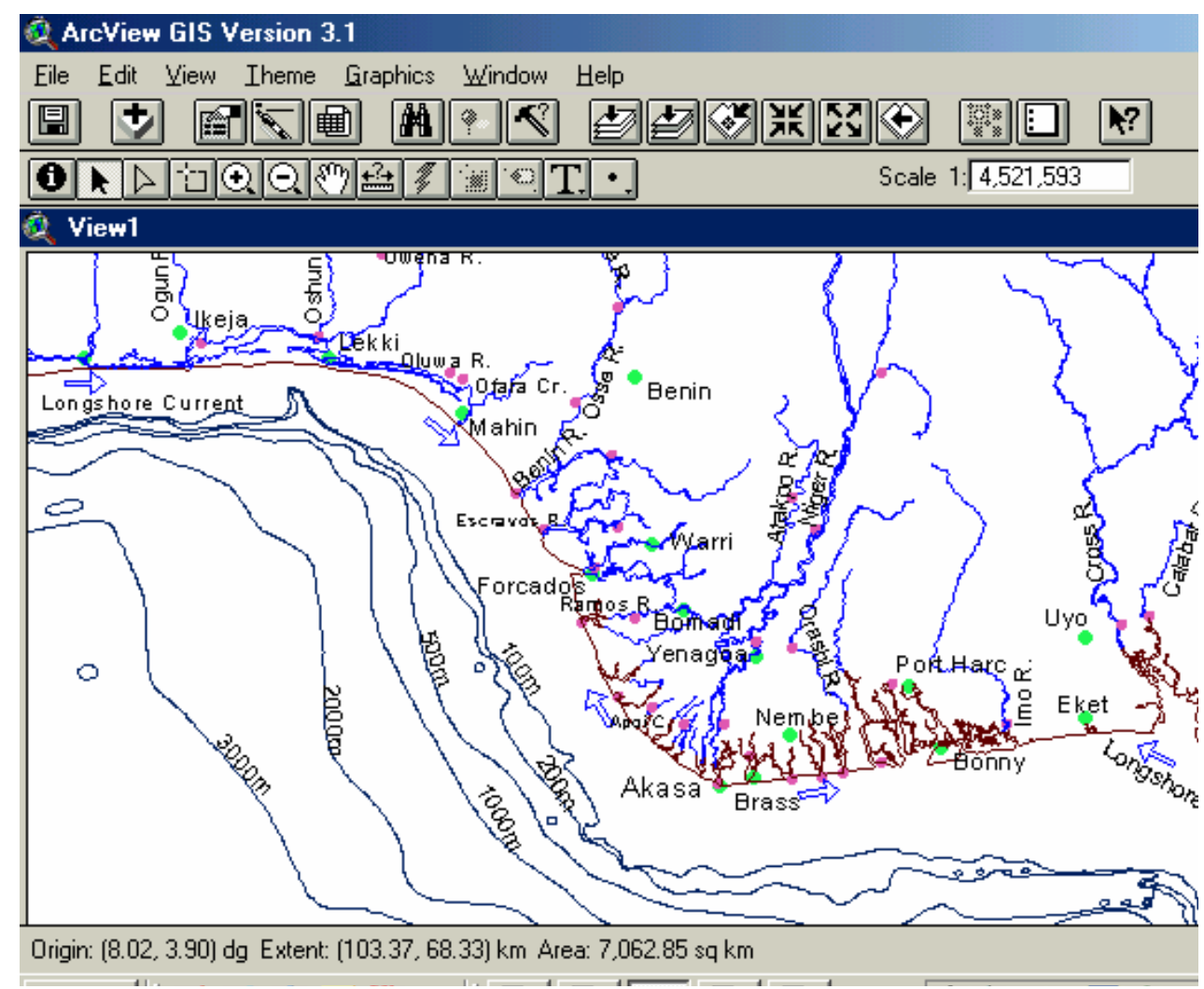

Fig 1 .0: Longshore Current Directions Along Nigerian Coastline

\section{NEW OIL SPILL ADVECTION MODEL}

The vector sums of the speed and directions of wind drift current, Eulerian surface wave drift,tides, ocean current and longshore current considered above will move the oil along our coastal waters. These vector sums is the model's advection speed and direction, and are given by the equations below.

$S N M=\sqrt{ }($ (SWDC Cos $\theta W D C+$ SSWD Cos $\theta S W D+$ STIDE Cos $\theta$ TIDE + SOC Cos $\theta \mathrm{OC}+$
SLC Cos $\theta L C) 2+($ SWDC Sin $\theta W D C+$ SSWDSin $\theta$ SWD + STIDE Sin $\theta$ TIDE + SOC $\sin \theta O C$ + SLC Sin $\theta L C$ )2) .......1.0 $\theta N M=$ Tan-1 (SWDC Sin $\theta W D C+$ SSWD Sin $\theta S W D$ + STIDE Sin $\theta$ TIDE + SOC Sin $\theta O C+$ SLC Sin $\theta L C) /(S W D C$ Cos $\theta W D C+$ SSWD Cos ӨSWD + STIDE Cos $\theta$ TIDE+ SOC Cos $\Theta o c$

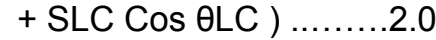

Where 
SWDC $=$ Speed of wind drift current

OWDC $=$ Direction of wind drift current

SSWD = Speed of Eulerian surface wave drift current

$\theta S W D=$ Direction of Eulerian surface wave drift

current

STIDE $=$ Speed of tide

$\theta T I D E=$ Direction of tide.

SOC $=$ Speed of ocean current.

$\theta O C=$ Direction of ocean current.

$\mathrm{SLC}=$ Speed of longshore current

$\theta L C=$ Direction of longshore current

In addition to the new model developed, we also looked into existing equations governing the fate of oil on water. We incorporated equations for the rate of spreading and evaporation of oil spill on water to our model. These equations are the most important factors in the determination of the fate of oil spill. Fay's (1971) spreading theory is used in the model. In the model, oil spill is assumed to spread radially under steady gravity and viscous forces, thus Fay's radial spreading formula for gravity and inertial forces is used. The formula developed by Mackay (1980) is used to calculate the evaporate rate of oil in the model. The new trajectory model and the existing fate model was written in the Visual Basic Environment (Windows based). This was done so as to make the model user friendly, by making use of its powerful graphical user interface. Programming in the visual basic environment also enables us to link the model with a base map of the Nigerian coastal areas in a MapInfo GIS environment.

Study Area and Hypothetical Simulations of Oil Spill Position with the Model: An hypothetical spill site around OPL 250 located about $150 \mathrm{~km}$ off the Nigerian coastline was chosen as the study area. The actual spill position is longitude $4^{\circ} 30^{\prime} 46.20^{\prime \prime} \mathrm{E}$ and latitude $4^{\circ} 25^{\prime} 39.80^{\prime \prime} \mathrm{N}$ and were made for wet and dry seasons for the study area above. The simulations for the wet and dry seasons were done in four phases for each season. For phase one, simulations were made from the spill point up to a point around the $100 \mathrm{~m}$ isobath. In phase two, simulations were made from the point around the $100 \mathrm{~m}$ isobath to a point about $20 \mathrm{~km}$ to the coastline. Simulations for phase three were made from the point about $20 \mathrm{~km}$ to the coastline up to another point about $10 \mathrm{~km}$ to the coastline. Simulations for the last phase were made from the point about $10 \mathrm{~km}$ to the coastline up to the coastline. The reason for making the simulations in four phases is that the effect of tides is negligible for the deep sea, while the tidal effect increases as one moves closer to the coastline.
We have to vary the amplitudes and phases of tides along the coastal waters. The simulated oil spill points for all the four phases for the wet season were plotted in Map Info GIS software which is linked with the model in Visual Basic environment. The Oil Spill Trajectory for the wet season is shown in Figure 3.1 below. The result of the simulation for wet season shows that the oil spill moves slower in deep sea and faster between the distance of $10 \mathrm{~km}$ to $20 \mathrm{~km}$ from the shoreline. The reason for this is that in the deep sea, there is no tidal effect while the tidal effect is prevalent in the $10 \mathrm{~km}$ to $20 \mathrm{~km}$ region. Also, the net effect of the longshore current and tides increased the speed of the oil spill near the shoreline.Tides and ocean currents are the major factors responsible for oil spill movement along our coastline during the wet season. For the study location above, the magnitude of effective current velocity and directions remained the same throughout the four phases. The magnitudes of these are $.223 \mathrm{~m} / \mathrm{s}$ and 900 respectively.

Wind drift current and waves are secondary factors for moving oil spill during the wet season. The wind drift current remained constant for the four phases. The wind drift current is $1.94 \%$ of the wind speed in deep water, $0.81 \%$ of wind speed in shallow water. The wind drift velocity tends to zero along the oastline. The wave velocity increases as one moves towards the shoreline. The magnitude of the wave velocity is lower than that of the wind drift in the first three phases, but higher than that of the wind drift current in the fourth phase. The effect of waves is negligible in deep sea $(1000 \mathrm{~m}+)$ but cannot be dispensed within shallow sea or near the coastline.

The simulated oil spill for wet season reached the shore (around Penington River) after 104hours(about 4.5 days). The oil spill will continue to move along the shoreline towards Escravos (i.e. in the direction of the longshore current). When the tide is high, the oil spill will move into the coastal lands and negatively impact the ecosystem.By the end of the 104 hours a total of $94,525.660$ barrels of oil would have evaporated. This amount represents $16.88 \%$ of the 560,000 barrels of oil spilt. In addition the Slick area at the end of the 104 hours would be $1782.058 \mathrm{~km} 2$. The simulated oil spill points for all the four phases for the dry season were plotted in Maplnfo GIS software which is linked with the model in Visual Basic environment. The Oil Spill,Trajectory for the dry season is shown in Figure 3.0 below. 


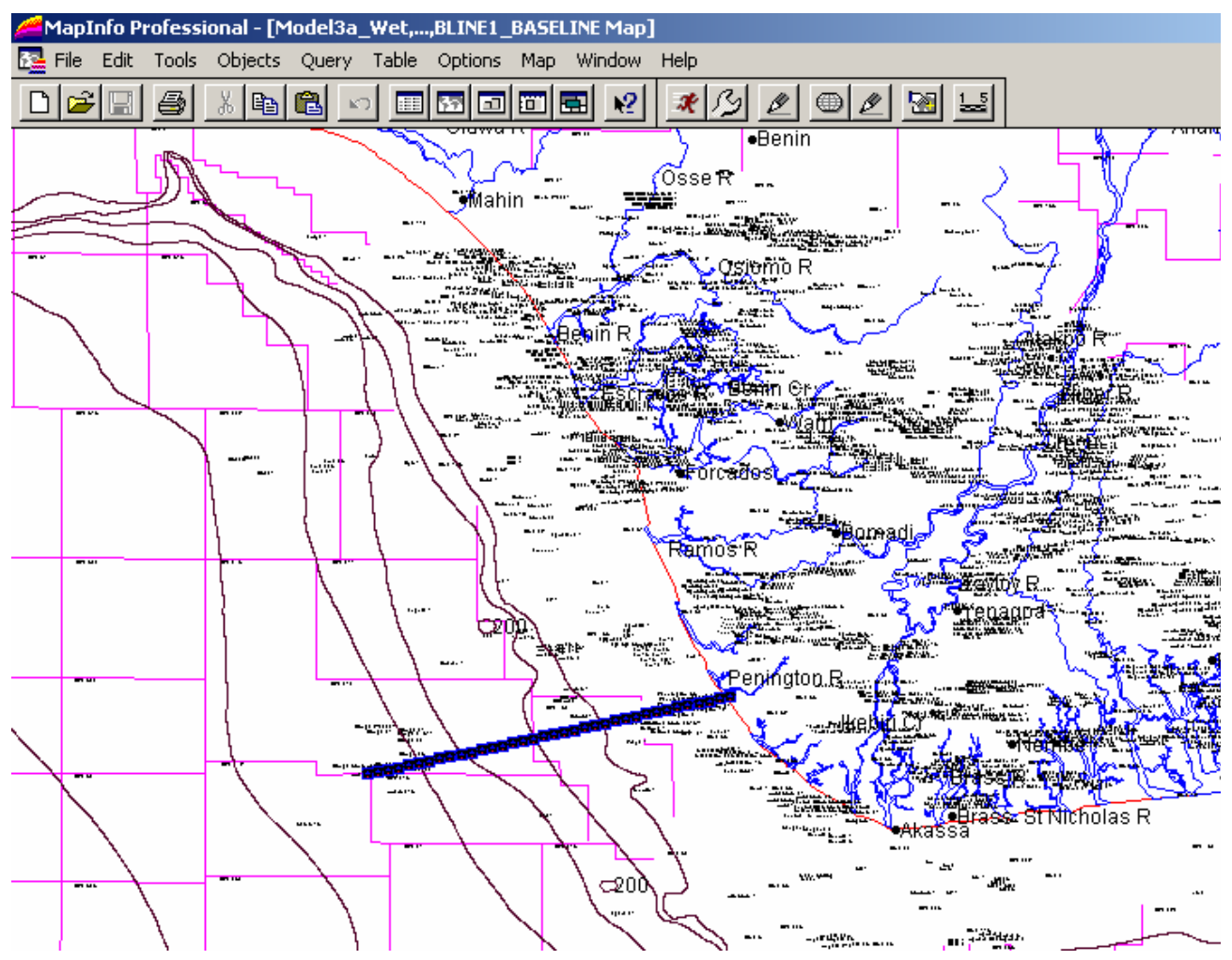

Fig 2.0: Oil Spill Trajectory for the Wet Season

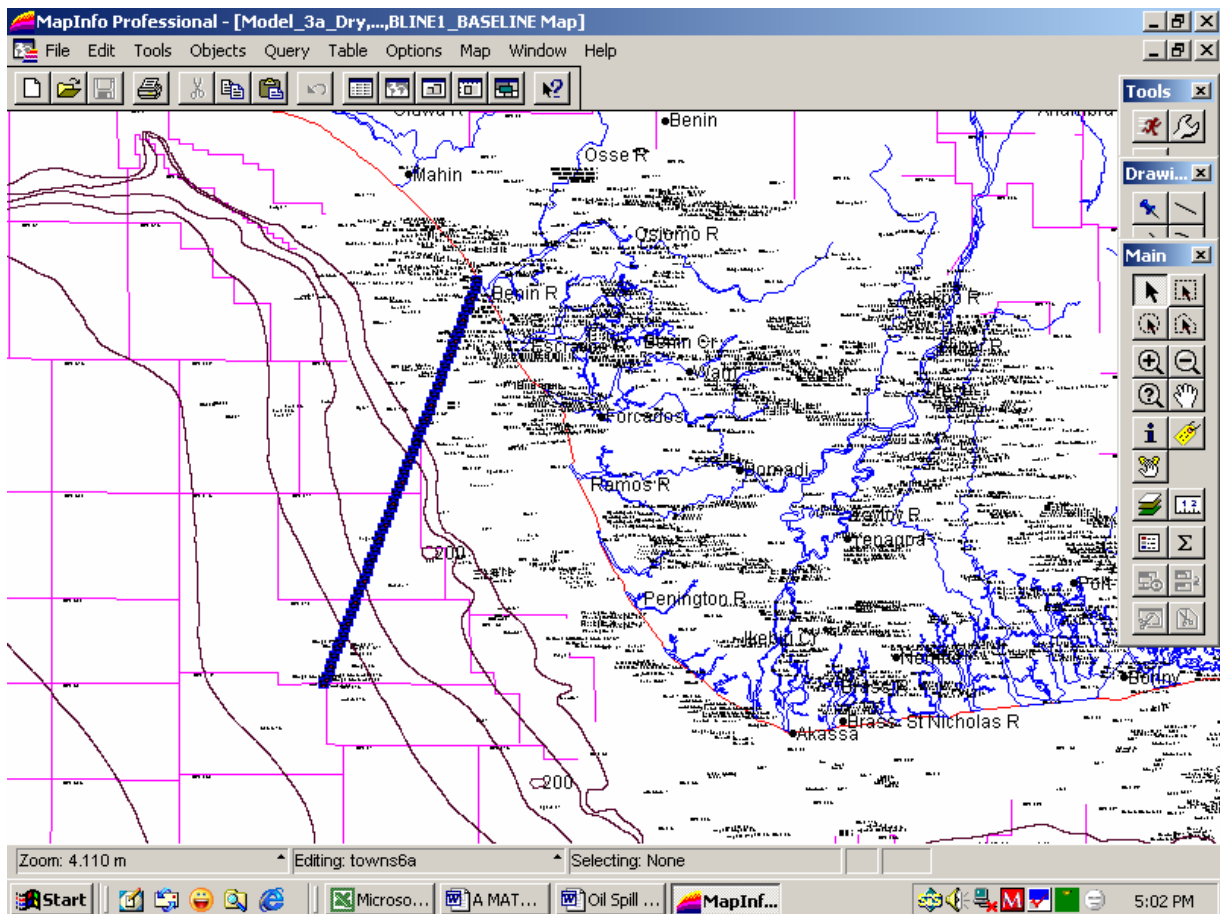

Fig:3.0: The Oil Spill,Trajectory for the dry season 
The result of the simulation for dry season shows that the oil spill moves also moves slower in deep sea and faster between the distance of $10 \mathrm{~km}$ to $20 \mathrm{~km}$ from the shore line during the dry season. The reason for this is that in the deep sea, there is no tidal effect while the tidal effect is prevailent in the $10 \mathrm{~km}$ to $20 \mathrm{~km}$ boundary. Also, the net effect of the longshore current and tides increased the speed of the oil spill near the shoreline. Tides and ocean currents are also the major factors responsible for oil spill movement along our coastline during the dry season. For the study location above, the magnitude of effective current velocity and directions remained the same throughout the four phases. The magnitudes of these are $.17 \mathrm{~m} / \mathrm{s}$ and 00 respectively. Oil spill moves slower during the dry season. The reason for this is that the magnitude of the ocean current is lesser during the dry season. Wind drift current and waves are also secondary factors for moving oil spill during the dry season. The wind drift current remained constant for the four phases. The wind drift current is

about $2 . \%$ of the wind speed during the dry season. The wave velocity increases as one moves towards the shoreline. The magnitude of the wave velocity is lower than that of the wind drift in the first three phases, but higher than that of the wind drift current in the fourth phase. The effect of waves is negligible in deep sea $(1000 \mathrm{~m}+)$ but cannot be dispensed with in shallow sea or near the coastline .

The results from the model for dry season indicate that the oil spill reached the shore (at the entrance of Benin River) after 162hours (6.5days). The oil spill would then move towards Forcados (i.e. in the direction of the longshore current) around where its flow would be affected by the longshore current coming from Penington end. The oil spill would be stationary at this point, and move into the coastlands during high waters.By the end of the 162 hours a total of 147241.894 barrels of oil would have evaporated. This amount represents $26.293 \%$ of the 560,000 barrels of oil spilt. In addition the slick area at the end of the 162 hours would be $1628.440 \mathrm{~km}^{2}$.

\section{Biological remediation:}

The use of biological remediation has also been implemented in areas of the delta to detoxify and restore ecosystems damaged by oil spills. Bioremediation involves biological components in the remediation or cleanup of a specific site. A study conducted in Ogbogu located in one of the largest oil producing regions of Nigeria has utilized two plant species to clean up spills. The first stage of cleanup involves Hibiscus cannabinus, a plant species indigenous to West Africa. $H$. cannabinus is an annual herbaceous plant originally used for pulp production. This species has high rates of absorbency and can be laid down on top of the water to absorb oil. The oil saturated plant material is then removed and sent to a safe location where the hydrocarbons can be broken down and detoxified by microorganisms. The second stage of bioremediation involves a plant known as Vetiveria zizanioides, a perennial grass species. $V$. zizanioides has a deep fibrous root network that can both tolerate chemicals in the soil and can also detoxify soils through time requiring little maintenance. The people of Ogbogu hope to use these methods of bioremediation to improve the quality of drinking water, soil conditions, and the health of their surrounding environment.

Within the Imo State of Nigeria, a study was conducted in the city of Egbema to determine the microfloral communities present at the site of an oil spill. These microorganisms have the ability to break down the oil, decreasing the toxic conditions. This is recognized as another method of bioremediation and scientists are trying to determine whether the properties these microorganisms possess can be utilized for the cleanup of future spills. ${ }^{[23]}$

However bleak this situation may seem for the Niger Delta region there are clearly alternatives that can be implemented to save it from future contamination. Satellite imagery combined with the use of Geographical Information Systems (GIS) can be put to work to quickly identify and track spilled oil. To hasten the cleanup of spills, regional cleanup sites along the problem areas could help contain spills more quickly. To make these tasks feasible more funding must be provided by the stakeholders of the oil industry. Nongovernmental organizations will keep fighting the damaging effects of oil, but will not win the battle alone.

Approaches to Bioremediation: The two main approaches to oil spill bioremediation are bioaugmentation and biostimulation. Bioaugmentation involves the use of beneficial microbes that have an affinity towards a specific pollutant. Typically, these microbes are suspended by a stabilizing agent and lie dormant until activated in solution and applied together with micro-nutrients and stimulants. Bioaugmentation allows one to control the nature of the biomass. It ensures that the proper team of microbes is present in the spilled soil in sufficient type, number, and compatibility to attack 
the constituents effectively and break them into their most basic compounds (Venosa et al., 1996;McKee and Mendelssohn, 1995). Biostimulation on the other hand involves aeration and the addition of selected micronutrients and sometimes topsoil in appropriate quantities (Shekwolo, 2005; Swannell et al., 1999). It is only effective when indigenous microbial populations, present in the substrate, are high enough to degrade the $\mathrm{PHC}$, and when these microbes can readily adapt to foreign substrates.Mishra et al. (2001) argued that since microorganisms capable of degrading oil usually grow at the expense of one or more components of crude oil, and these bacteria are ubiquitous, there is usually no reason to add $\mathrm{PHC}$ biodegraders unless the indigenous bacteria are incapable of degrading one or more important components. The size of the hydrocarbon degrading bacteria population usually increases rapidly in response to oil contamination, and it is very difficult, if not impossible to increase the microbial population over that which can be achieved by biostimulation alone (Lin and Mendelssohn, 1998). The carrying capacity of most environments is probably determined by factors such as predation by protozoan, the oil surface area, or scouring of attached biomass by wind activity that are not affected by bioaugmentation, and added bacteria seem to compete poorly with the indigenous population. Therefore, it is unlikely that they will persist in a contaminated soil even when they are added in high numbers. Hence, bioaugmentation may not have any long term beneficial effects in clean up operations.Biostimulation involves the addition of rate-limiting nutrients to accelerate degradation by indigenous microbes.This assumes that every organism needed to accomplish the desired treatment-results is present (Mishra et al., 2001). Though it is not certain that those organisms present are the most suitable to degrade the pollutant. When an oil spill occurs, it results in a huge influx of carbon into the impacted environment. Supplying enough nitrogennous nutrients to the cultures to enable their proliferation present serious problems, since sea, river, or lake water and soil have little nitrogen and phosphorus, rapid oil utilization will require external supplies of these elements for the oil-consuming microorganisms. Carbon is the basic structural component of living matter, and in order for the indigenous microorganisms to be able to convert this carbon into more biomass, they need significantly more nitrogen and phosphorous than is normally present in the soil (Wright et al., 1997). Both of these essential elements are ingredients of protein and nucleic acids of living organisms, and therefore should be adequately provided.

\section{CONCLUSION AND RECOMMENDATIONS :}

Oil spills are caused by human errors and carelessness, but sometimes by natural disasters such as hurricanes or earthquakes. Deliberate acts by terrorists, countries at war, sabotage and bunkering, or illegal dumpers however, prove that oil spills are not always accidents. Some oil from any spill is degraded into simpler substances naturally by microorganisms. Use of biosurfactants have been shown to be of desirable characteristics, therefore it is one of the best approaches suitable for emulsification of crude oil spills for biodegradation. The biodegradation process is relatively slow, and when an oil spill occurs, workers must act fast to protect the environment. Most crude oils are inherently biodegradable, but they contain essentially no nitrogen, phosphorous or other trace elements that are necessary to stimulate the microbes that degrade the oil.

In the same vein,the Nigeria Sat-1, would help in monitoring oil spill by providing the spill position which would serve as input data into the oil spill model. It would also give the extent of coastal water and coastal areas polluted. These information are vital for quick clean up of oil impacted areas.

In order to reduce the response time and qualify the decision-making process, application of Geographic Information Systems (GIS) as an operational tool has been suggested.

Information on the exact position and size of the oil spill can be plotted on maps in GIS and a priority of the combat efforts and means according to the identified coastal sensitive areas can

be carried out.

The creation of regional spill response centres along coastlines would help in managing oil spill problems (Smith and Loza, 1994). The centres will use oil spill models for combating oil spill problems. Using data collected with an airborne system to input one or several new starting point(s) into the model, will improve the accuracy of the further predictions.

\section{REFERENCES}

Anderson CM, LaBelle RP (2000). Update of comparative occurrence rates for offshore oil spills. Spill Sci. Technol. Bull. 6(5/6): 303-321. 
Borjana KT, George RI, Nelly EC (2001). Biosurfactant production by a new Pseudomonas putida strain. Z. Naturforsch. 57: 356-360

Cameotra S.S, Pruthi V (1997). Production and properties of a biosurfactant synthesized by Arthrobacter protophormiae - an Antarctic strain. World J. Microbiol. Biotechnol. 13:137-139

Clark JF, Washburn L, Hornafius J.S, Luyendyk B.P (2000). Dissolved hydrocarbon flux from natural marine seeps to the southern California Bight. J. Geophys. Res. 105(5): 509-522.

Clester S.M, Hornafius J.S, Scepan J, Estes JE (1996). Quantification of the relationship between natural gas seepage rates and surface oil volume in the Santa Barbara Channel, supplement to EOS. Transactions AGU. 77(46): 419.

Coronelli TV (1996). Principles and Methods of intensification of hydrocarbon biodegradation in the environment. Mikrobiologija. 32: 579-585.

ljah U.J.J, Antai SP (2003). Removal of Nigerian light crude oil in soil over a 12-month period. Int. Biodeterior. Biodegrad. 51: 93-99

Kim I (1996). Harnessing the Green Clean. Chem. Eng., pp. 39-41.

Kvenvolden KA, Rosenbauer RJ, Hostettler FD, Lorenson TD (2000). Application of organic geochemistry to coastal tar residues from central California. Int. Geol. Rev. 42: 1-14.
Allen, J.R., 1965: Late Quaternary of the Niger Delta, and Adjacent Areas. Sedimentary Environments and Lithofacies AAPG V.49. p547-600.

Badejo, O.T. and Nwilo P.C., 2004: Management of Oil Spill Dispersal Along the Nigerian Coastal Areas. ISPRS Congress 2004, Istanbul, Turkey.

Gundlach E.R. and Murday, M.L., 1987: Oil Spill Sensitivity Atlas for Mauritius. Prepared for IMO, UNDP, Mauritius Ministry of Lands and Environment, 146pp.

Hoff, R., 1993: Bioremediation: An Overview of its Development and use for Oil Spill Clean Up. Mar. Pollut. Bull. 26, 476- 481.

Ibe, A.C., 1988: Coastline Erosion in Nigeria. University of Ibadan Press IMO/IPIECA, 1998: Sensitivity Mapping for Oil Spill Response. A Summary of the IMO/IPIECA Report. Vol 1.

Jelgersma, S., Van der Zijp, M., Brinkman, R., 1993: Sea Level Rise and the Coastal Lowlands in the Developing World. Journal of Coastal Research, Vol. 9, No. 4. pp 958-972.

NDES, 1997: Niger Delta Environmental Survey; Final Report, Phase I. Environmental Resources Managers Limited. Nigerian Coastal Erosion and Subsidence, 1991: Technical Report NO. 1. Prepared for EEC/Nigerian Coastal Erosion Research Project. Ed. B.I.C ljeoma. 137p.

Ntukekpo D.S.,1996: Spillage: Bane of Petroleum, UltimateWater Technology \$ Environment

Nwilo, P.C., 1995: Sea Level Variation and the Impacts in the Coastal Areas of Nigeria. Ph.D Thesis. University of Salford, UK (Unpublished). 